\title{
Lewis-base Adducts of Group 1B Metal(I) Compounds. Part 19.t Crystal Structures of Bis(1,10-phenanthroline)copper(I) Perchlorate and Dibromocuprate $(1) \ddagger$
}

\author{
Peter C. Healy \\ School of Science, Griffith University, Nathan, Queens/and 4111, Australia \\ Lutz M. Engelhardt, Vincent A. Patrick, and Allan H. White* \\ Department of Physical and Inorganic Chemistry, University of Western Australia, Nedlands, Western \\ Australia 6009
}

\begin{abstract}
The crystal structures of the title compounds $\left[\mathrm{Cu}(\text { phen })_{2}\right]\left[\mathrm{ClO}_{4}\right](1)$ and $\left[\mathrm{Cu}(\mathrm{phen})_{2}\right]\left[\mathrm{CuBr}_{2}\right](2)$ (phen $=1,10$-phenanthroline) have been established by single-crystal $X$-ray diffraction methods at $295 \mathrm{~K}$. Crystals of (1) are monoclinic, $P 2 / c, a=10.037(3), b=14.518(6), c=7.672(3) \AA$ $\beta=97.82(3)^{\circ}, Z=2$. $R$ was 0.056 for 709 independent 'observed' reflections. Crystals of $(2)$ are monoclinic, $C 2 / c, a=17.206(4), b=13.365(2), c=10.920(3) \AA, \beta=115.43(2)^{\circ}, Z=4 . R$ was 0.048 for 1091 independent 'observed' reflections. Surprisingly, complex (2) is not a di- $\mu$-bromobridged dimer, [(phen) $\mathrm{CuBr}_{2} \mathrm{Cu}$ (phen)], but ionic $\left[\mathrm{Cu}(\text { phen })_{2}\right]\left[\mathrm{CuBr}_{2}\right]$. In both (1) and (2), the $\left[\mathrm{Cu}(\text { phen })_{2}\right]^{+}$cation has crystallographic 2 symmetry; in (1), the 2 axis passes through the ligands so that the overall symmetry is close to 222 , but in (2) it passes between the ligands, so that the cation geometry is very far removed from 222 symmetry. In (1), $\mathrm{Cu}-\mathrm{N}$ are $2.045(8), 2.053(9) \AA$; in (2), 2.006 (8) and 2.071 (5) $\AA$. The linear anion in (2) has $\mathrm{Cu}-\mathrm{Br} 2.209(2)$ and 2.223(2) $\AA$. The dihedral angles for each compound differ significantly, being $49.9^{\circ}$ for (1) and $76.8^{\circ}$ for (2), the former being the lowest value yet observed for a copper(1) cation with two bidentate ligands.
\end{abstract}

For species of the type $\left[\mathrm{ML}_{n}\right]^{m+}[\mathrm{L}=1,10$-phenanthroline (phen) or 2,2'-bipyridyl (bipy)], a considerable array of structural information is available when $n=3$, where the detailed stereochemistry has been examined as a function of metal size. ${ }^{1}$ For $n=4$, the number of derivatives available is much smaller, and the only structurally authenticated example is the unusual species [U(bipy) ${ }_{4}$ ] with cubic stereochemistry, ${ }^{2}$ while hydrates ostensibly with this stoicheiometry have been shown to have mixed-ligand co-ordination spheres, ${ }^{3}$ with ligands of crystallization, e.g. $\left[\mathrm{M}(\mathrm{phen})_{2}\left(\mathrm{H}_{2} \mathrm{O}\right)_{x}\right]\left[\mathrm{ClO}_{4}\right]_{2} \cdot 2$ phen $(x=2$ or $4, \mathrm{M}=\mathrm{Sr}$ or $\mathrm{Ba})$. For $n=2$, no structurally authenticated examples are known at all, although for the sterically demanding ligand 2,9-dimethyl-1,10-phenanthroline (dmphen) an array of $\left[\mathrm{Cu}(\mathrm{dmphen})_{2}\right]^{+}$salts have been characterized ${ }^{4}$ Although the copper atoms in the $[\mathrm{Cu}-$ $\left.(\mathrm{dmphen})_{2}\right]^{+}$salts are four-co-ordinate it is not clear that this need be so in such complexes of the unsubstituted ligand where the metal size is such that scope for interaction with solvent or counter ions is available. In order to provide information about the cation stereochemistry in such species, and to provide a baseline study for such a complex in the context of the results of the preceding paper, we have undertaken the structure determination of the perchlorate salt, $\left[\mathrm{Cu}(\text { phen })_{2}\right]\left[\mathrm{ClO}_{4}\right](1)$, prepared by the reaction of $\left[\mathrm{Cu}\left(\mathrm{CH}_{3} \mathrm{CN}\right)_{4}\right]\left[\mathrm{ClO}_{4}\right]$ with excess phen $\cdot \mathrm{H}_{2} \mathrm{O}$ in acetonitrile under an atmosphere of argon.

In the preceding paper ${ }^{5}$ we have described the structures of a number of derivatives of stoicheiometry $\mathrm{CuXL}^{\prime}\left(\mathrm{L}^{\prime}=\right.$ phen or dmphen) showing how binuclear $\mathrm{L}^{\prime} \mathrm{CuX}_{2} \mathrm{CuL}^{\prime}$, relatively unstrained for $L^{\prime}=$ phen $(X=I)$ becomes progressively more strained on passing to $L^{\prime}=\operatorname{dmphen}(X=I)$ and then to $L^{\prime}=$ dmphen $(X=B r)$, resulting in disruption to the monomer for

\section{† Part 18 is ref. 5.}

$\ddagger$ Supplementary data available: (No. SUP 56324, 10 pp.): thermal parameters, $\mathrm{H}$-atom co-ordinates, least-squares planes data, non- $\mathrm{H}$ atom ligand distances and angles. See Instructions for Authors, J. Chem. Soc., Dalton Trans., 1985, Issue 1, pp. xvii-xix. Structure factors are available from the editorial office.
$\mathrm{L}^{\prime}=\mathrm{dmphen}(\mathrm{X}=\mathrm{Cl})$. At the time of execution of that work, we were only able to prepare microcrystalline samples of $[\mathrm{CuX}($ phen $)](\mathrm{X}=\mathrm{Br}$ or $\mathrm{Cl})$, none of which was suitable for $X$-ray analysis. We did, however, isolate from the products of reaction of $\mathrm{CuBr}$ with excess phen $\cdot \mathrm{H}_{2} \mathrm{O}$ in dichloromethane, a dark brown-red irregular crystalline material which was shown by structural analysis to be the ionic species $\left[\mathrm{Cu}\left(\mathrm{pher}_{1}\right)_{2}\right]$ $\left[\mathrm{CuBr}_{2}\right](2)$; thus providing a second example of the $[\mathrm{Cu}-$ (phen $\left.)_{2}\right]^{+}$cation, as well as the novel $\left[\mathrm{CuBr}_{2}\right]^{--}$anion. Unlike the perchlorate salt, complex (2) appears resistant to oxidation on prolonged exposure to the atmosphere.

In this paper we report the results of the structural analyses of (1) and (2).

\section{Experimental}

Crystallography. - General details of the structure determinations are given in the preceding paper. Atomic co-ordinates for (1) and (2) are given in Tables 1 and 2 respectively.

Crystal data for $\left[\mathrm{Cu}(\mathrm{phen})_{2}\right]\left[\mathrm{ClO}_{4}\right](\mathbf{1}) . \mathrm{C}_{24} \mathrm{H}_{16} \mathrm{ClCuN}_{4} \mathrm{O}_{4}$, $M=523.4$, monoclinic, space group $P 2 / c\left(C_{2 h}^{4}\right.$, no. 13$)$, $a=10.037(3), b=14.518(6), c=7.672(3) \AA, \beta=97.82(3)^{\circ}$, $U=1$ 107.5(7) $\AA^{3}, D_{c}(Z=2)=1.57 \mathrm{~g} \mathrm{~cm}^{-3}, F(000)=532$, monochromatic Mo- $K_{\alpha}$ radiation, $\lambda=0.71069 \AA, \mu=12.1$ $\mathrm{cm}^{-1}$. Specimen: $0.08 \times 0.15 \times 0.42 \mathrm{~mm}$ (capillary). $2 \theta_{\max .}=$ $40^{\circ}, N=1100, N_{\mathrm{o}}=709, R=0.056, R^{\prime}=0.042 ; T=295 \mathrm{~K}$. Crystal data for $\left[\mathrm{Cu}(\mathrm{phen})_{2}\right]\left[\mathrm{CuBr}_{2}\right]$ (2). $\mathrm{C}_{24} \mathrm{H}_{16} \mathrm{Br}_{2} \mathrm{Cu}_{2} \mathrm{~N}_{4}$, $M=647.4$, monoclinic, space group $C 2 / c\left(C_{2 h}^{6}\right.$, no. 15$), a=$ $17.206(4), b=13.365(2), c=10.920(3) \AA, \beta=115.43(2)^{\circ}, U=$ $2267.8(8) \AA^{3}, D_{\mathrm{c}}(Z=4)=1.90 \mathrm{~g} \mathrm{~cm}^{-3}, F(000)=1264, \mu_{\mathrm{Mo}}=$ $57 \mathrm{~cm}^{-1}$. Specimen: cuboid, $0.15 \mathrm{~mm} .2 \theta_{\max .}=50^{\circ}, N=1831$, $N_{\mathrm{o}}=1091, R=0.048, R^{\prime}=0.052 ; T=295 \mathrm{~K}$.

Abnormal features for (1). Both cation and anion have crystallographically imposed symmetry in $P 2 / c$; although intrinsically capable of conforming to this symmetry, the anion is disordered. The oxygen atoms were modelled from difference-map information as five fragments, refined with isotropic thermal parameters and variable populations; although the final total 
Table 1. Non-hydrogen atomic co-ordinates for $\left[\mathrm{Cu}(\mathrm{phen})_{2}\right]\left[\mathrm{ClO}_{4}\right](1)^{a, b}$

\begin{tabular}{|c|c|c|c|c|c|c|}
\hline \multirow[b]{2}{*}{ Atom } & \multicolumn{3}{|c|}{ Ligand A } & \multicolumn{3}{|c|}{ Ligand B } \\
\hline & $x$ & $y$ & $z$ & $x$ & $y$ & $z$ \\
\hline \multicolumn{7}{|c|}{ Cation } \\
\hline $\mathrm{Cu}^{c}$ & 0 & $0.2201(1)$ & $\frac{1}{4}$ & & & \\
\hline $\mathbf{N}$ & $0.1185(9)$ & $0.1134(5)$ & $0.3523(11)$ & $0.1186(8)$ & $0.3278(5)$ & $0.1905(10)$ \\
\hline$C(1)$ & $0.2405(12)$ & $0.1136(8)$ & $0.4435(14)$ & $0.2434(13)$ & $0.3283(8)$ & $0.1426(14)$ \\
\hline $\mathrm{C}(2)$ & $0.3137(12)$ & $0.0326(11)$ & $0.4922(15)$ & $0.3132(12)$ & $0.4090(11)$ & $0.1211(15)$ \\
\hline$C(3)$ & $0.2563(15)$ & $-0.0490(9)$ & $0.4431(17)$ & $0.2562(17)$ & $0.4914(9)$ & $0.1465(16)$ \\
\hline$C(4)$ & $0.1290(13)$ & $-0.0534(7)$ & $0.3510(15)$ & $0.1277(13)$ & $0.4936(8)$ & $0.1988(14)$ \\
\hline$C(5)$ & $0.0652(9)$ & $0.0297(8)$ & $0.3023(12)$ & $0.0640(9)$ & $0.4111(7)$ & $0.2221(12)$ \\
\hline$C(6)$ & $0.0611(10)$ & $-0.1371(7)$ & $0.2963(17)$ & $0.0615(12)$ & $0.5780(7)$ & $0.2259(17)$ \\
\hline \multicolumn{7}{|l|}{ Anion } \\
\hline $\mathrm{Cl}^{\mathrm{c}}$ & $\frac{1}{2}$ & $0.7326(5)$ & $\frac{1}{4}$ & Population & & \\
\hline $\mathrm{O}(1)$ & $0.475(3)$ & $0.829(2)$ & $0.289(5)$ & $0.25(2)$ & & \\
\hline $\mathrm{O}(2)$ & $0.573(3)$ & $0.691(2)$ & $0.408(5)$ & $0.44(5)$ & & \\
\hline $\mathrm{O}(3)$ & $0.642(3)$ & $0.727(2)$ & $0.246(3)$ & $0.46(3)$ & & \\
\hline$O(4)$ & $0.545(2)$ & $0.778(2)$ & $0.115(5)$ & $0.48(5)$ & & \\
\hline$O(5)$ & $0.524(5)$ & $0.642(3)$ & $0.313(6)$ & $0.31(4)$ & & \\
\hline
\end{tabular}

${ }^{a}$ Estimated standard deviations are given in parentheses. ${ }^{b}$ Total oxygen population: $2 \times 1.94=3.88 .{ }^{c}$ Site symmetry 2 here and in the other Tables.

Table 2. Non-hydrogen atomic co-ordinates for $\left[\mathrm{Cu}(\mathrm{phen})_{2}\right]\left[\mathrm{CuBr}_{2}\right](2)$

\begin{tabular}{|c|c|c|c|c|c|c|}
\hline \multirow[b]{2}{*}{ Atom } & \multicolumn{3}{|c|}{ Ligand section A } & \multicolumn{3}{|c|}{ Ligand section $B$} \\
\hline & $x$ & $y$ & $z$ & $x$ & $y$ & $z$ \\
\hline \multicolumn{7}{|l|}{ Cation } \\
\hline $\mathrm{Cu}(1)^{*}$ & $\frac{1}{2}$ & $0.2169(1)$ & $\frac{1}{4}$ & & & \\
\hline $\mathrm{N}$ & $0.5977(4)$ & $0.2608(4)$ & $0.2086(6)$ & $0.5972(4)$ & $0.1377(4)$ & $0.4020(6)$ \\
\hline$C(1)$ & $0.5980(5)$ & $0.3201(6)$ & $0.1122(8)$ & $0.5956(5)$ & $0.0818(7)$ & $0.4998(9)$ \\
\hline$C(2)$ & $0.6697(6)$ & $0.3335(7)$ & $0.0841(8)$ & $0.6689(7)$ & $0.0318(7)$ & $0.5918(9)$ \\
\hline$C(3)$ & $0.7448(5)$ & $0.2861(7)$ & $0.1636(9)$ & $0.7448(6)$ & $0.0382(7)$ & $0.5785(9)$ \\
\hline C(4) & $0.7480(5)$ & $0.2238(6)$ & $0.2687(8)$ & $0.7479(5)$ & $0.0989(6)$ & $0.4777(7)$ \\
\hline$C(5)$ & $0.6726(5)$ & $0.2121(6)$ & $0.2865(7)$ & $0.6720(5)$ & $0.1478(5)$ & $0.3905(7)$ \\
\hline$C(6)$ & $0.8237(5)$ & $0.1713(7)$ & $0.3568(8)$ & $0.8234(5)$ & $0.1120(7)$ & $0.4557(8)$ \\
\hline \multicolumn{7}{|l|}{ Anion } \\
\hline $\mathrm{Cu}(2)^{*}$ & 0 & $0.2093(1)$ & $\frac{1}{4}$ & & & \\
\hline $\operatorname{Br}(1)^{*}$ & 0 & $0.3746(1)$ & 1 & & & \\
\hline $\operatorname{Br}(2)^{*}$ & 0 & $0.0430(1)$ & $\frac{1}{4}$ & & & \\
\hline
\end{tabular}

population (3.8) is not significantly different from the expected 4 and $\mathrm{Cl}-\mathrm{O}$ lie in the range $1.36(4)-1.46(3) \AA$, the associated angular geometry does not permit deconvolution of the disorder into a sensible array of superimposed species. Meaningful refinement of an ordered model in subgroup $P c$ was not possible.

Note that in (1) the two ligands are independent and denoted $A, B$ whereas in (2) one ligand is independent with sections denoted A,B.

\section{Discussion}

The results of the structure determination of (1) are consistent with the stoicheiometry and connectivity expected for $\left[\mathrm{Cu}(\text { phen })_{2}\right]\left[\mathrm{ClO}_{4}\right]$ (Figure 1). For (2) the results, surprisingly, are not consistent with the formation of a mononuclear species $[\mathrm{CuBr}(\mathrm{phen})]$, or a binuclear di- $\mu$-bromo-bridged species $\left[(\right.$ phen $) \mathrm{CuBr}_{2} \mathrm{Cu}($ phen $\left.)\right]$, as might be expected from the results reported in the preceding paper, or one of the many polymeric forms that have been observed for copper(I) halide-nitrogen base chemistry, and whose existence has been inferred for these systems as well, ${ }^{6}$ but instead are consistent with the formulation of an ionic complex $\left[\mathrm{Cu}(\mathrm{phen})_{2}\right]\left[\mathrm{CuBr}_{2}\right]$ by ligand disproportionation (Figure 2). The driving force behind such a transformation can only be the subject of speculation, but in view of the limited solubility of a number of these complexes, it may be that solvation effects are significant and that in due course the use of different solvents may induce the formation of different isomeric forms of the complex; in this context it is of interest to note the existence of the anion as $\left[\mathrm{CuBr}_{2}\right]^{-7}$ or $\left[\mathrm{Cu}_{2} \mathrm{Br}_{4}\right]^{2-} .8$

In both structures, the 2 symmetry elements of the space groups are imposed on all species. In the anion of (1), disorder is found; all other species are ordered. The anion of (2) is novel, and has only very recently been reported for the first time; ${ }^{7}$ all atoms lie on the 2 axis, so that it is truly linear. $\mathrm{Cu}-\mathrm{Br}(1,2)$ are $2.209(2), 2.223(2) \AA$ (Table 3), comparable with the value reported for the tetrabutylammonium salt ${ }^{7}[2.226(1) \AA]$.

In each structure the cation lies with the copper atom on a 2 axis; the dispositions of the ligands in relation to the symmetry axes differ, however. Ideally, it might be expected that the $[\mathrm{Cu}-$ $\left.(\text { phen })_{2}\right]^{+}$species should approach its maximum possible sym- 


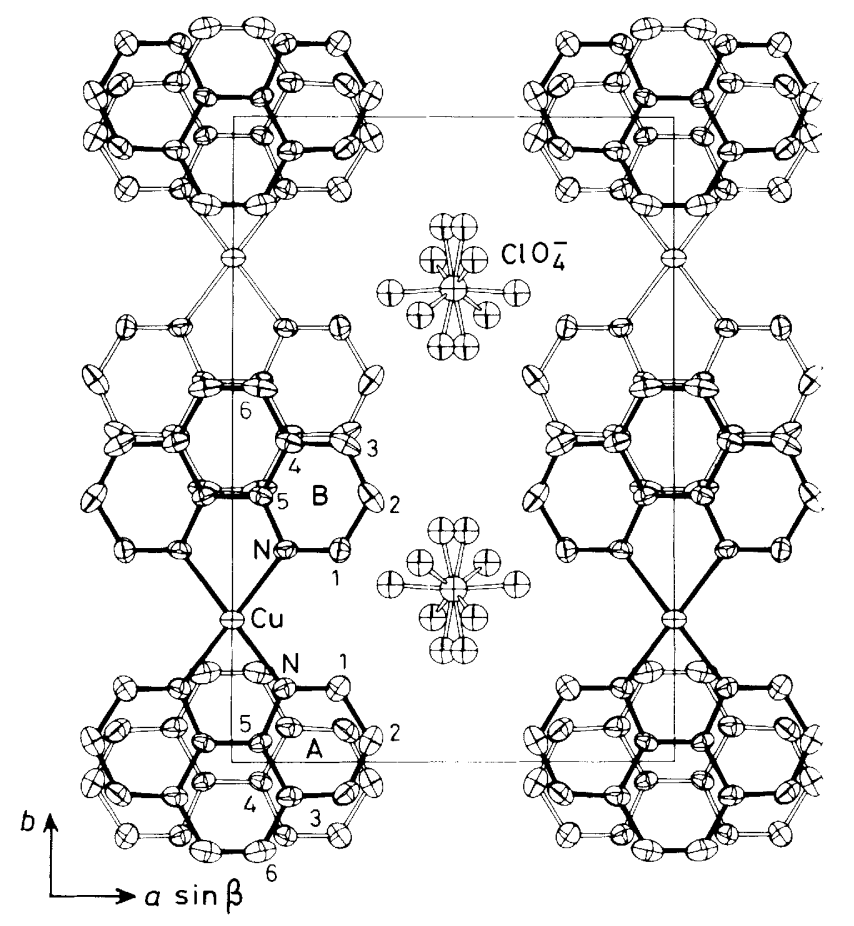

Figure 1. Unit-cell contents of (1) projected down $c ; 20 \%$ thermal ellipsoids are shown for the non-disordered non-hydrogen atom components. Non-hydrogen atom numbering is given

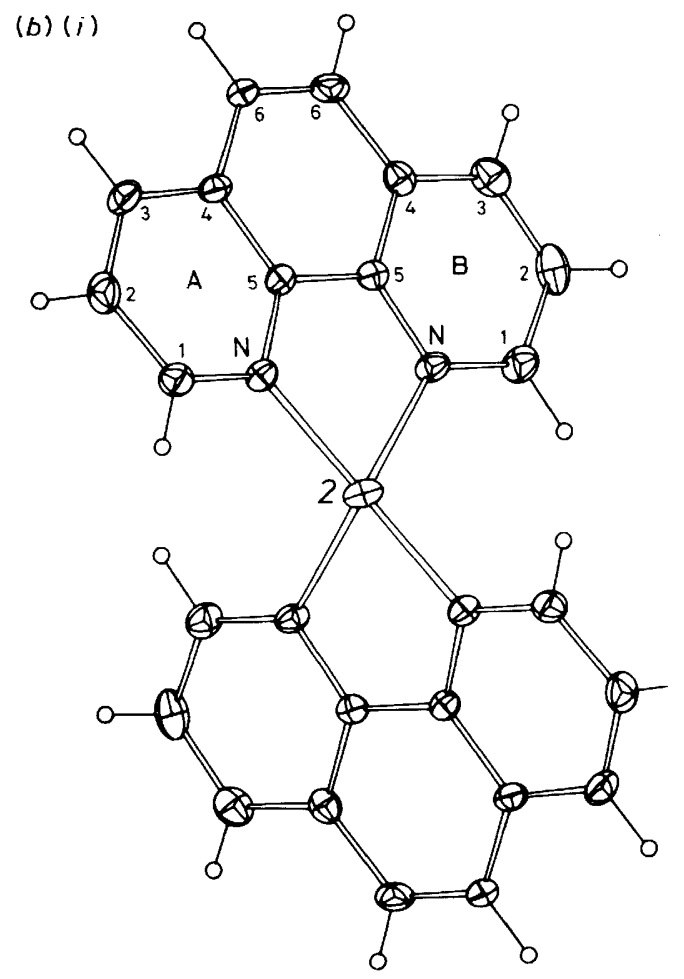

(a)

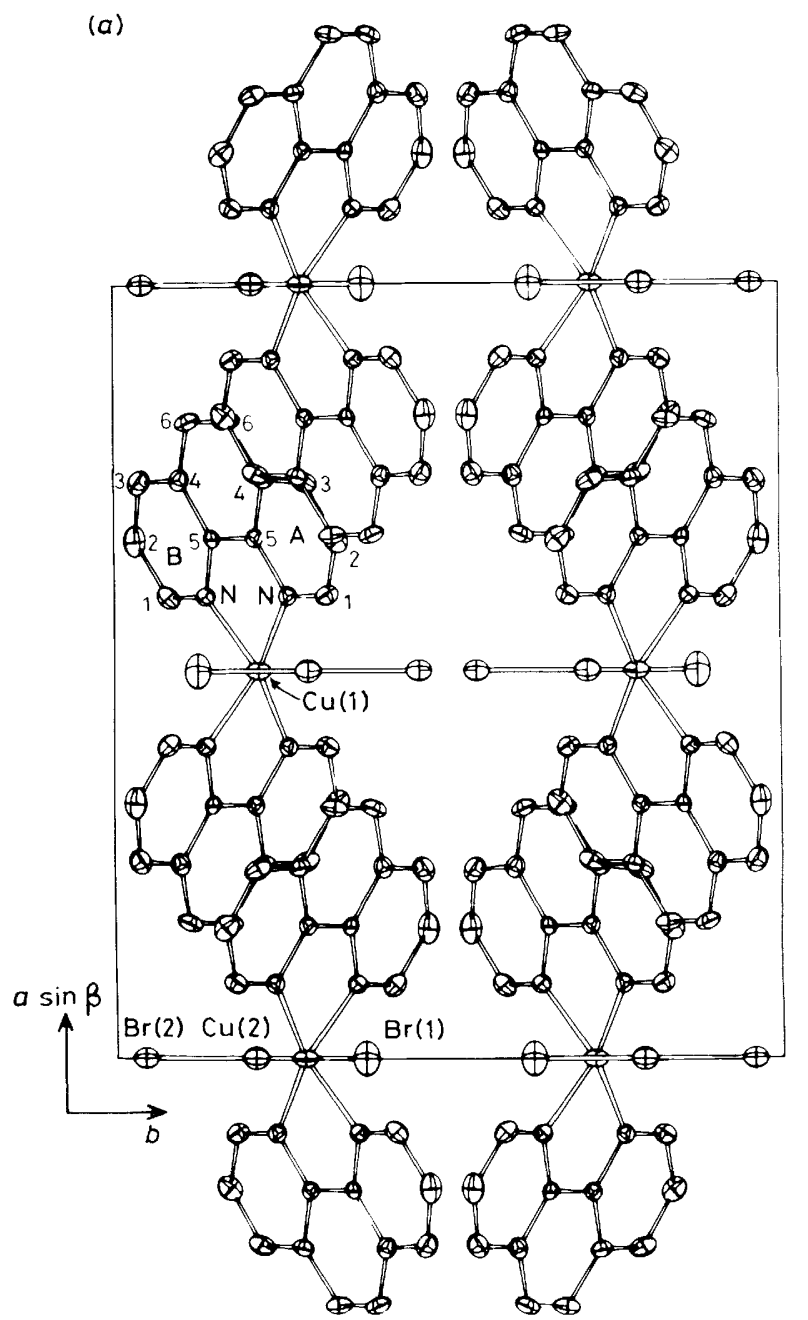

(ii)

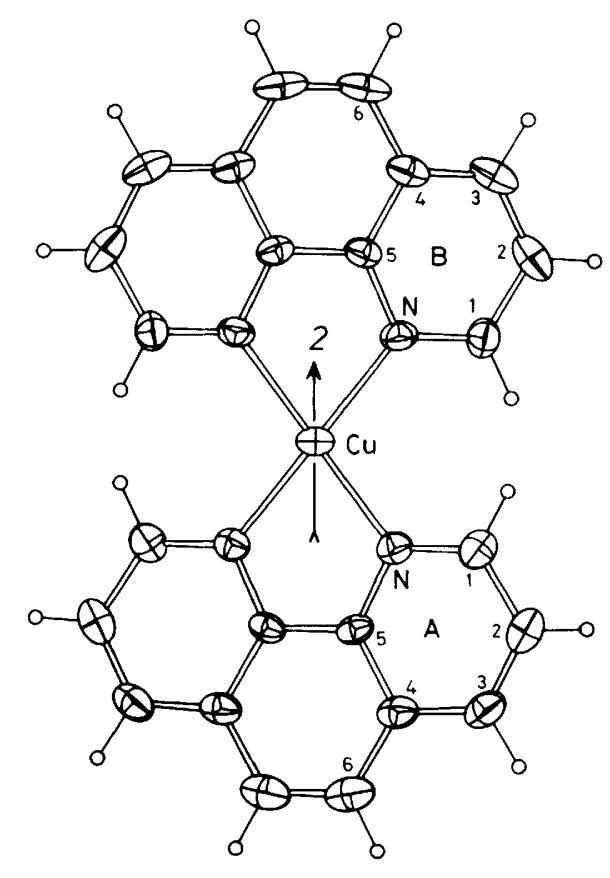

Figure 2. (a) Unit-cell contents of (2) projected down $c$. (b) (i) The cation of (2), projected down the two-fold axis. Hydrogen atoms have an arbitrary radius of $0.1 \AA$. (ii) The cation of (1), projected normal to the 2 axis and down the bisector of $\mathrm{N}(\mathrm{A})-\mathrm{Cu}-\mathrm{N}(\mathrm{B})$ for comparison 
$(a)$

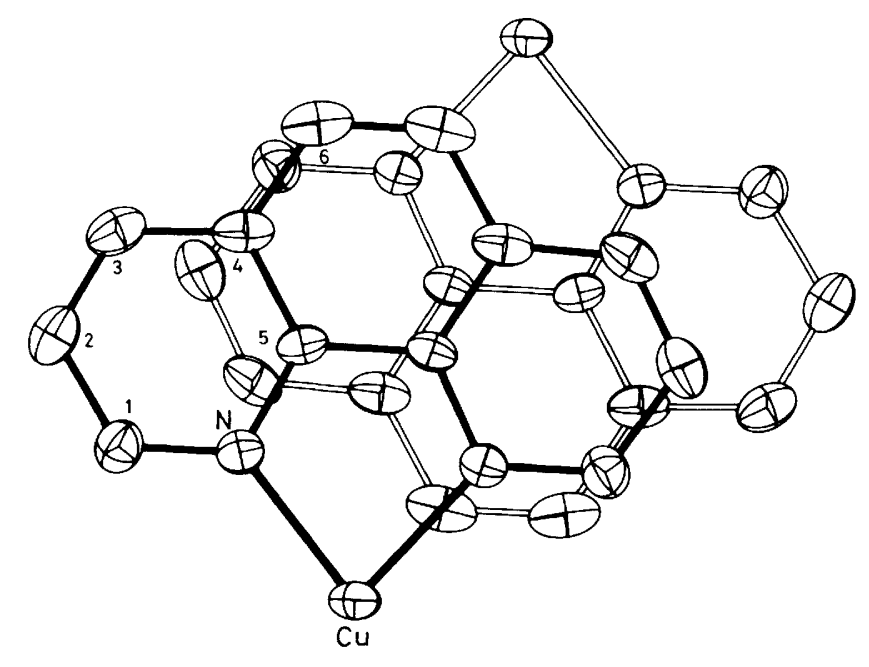

(b)

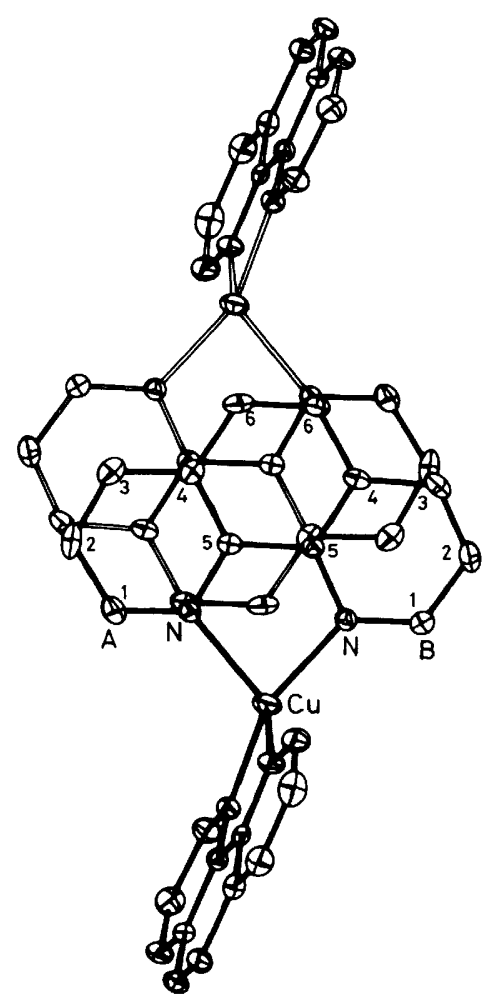

Figure 3. Projection normal to the ligand plane, showing intercation contacts for $(a)(1)$ and $(b)(2)$

Table 3. Metal-atom environments of (1) and $(2){ }^{a}$ distances $(\AA)$ and angles $\left({ }^{\circ}\right)$

\begin{tabular}{|c|c|c|c|}
\hline \multicolumn{4}{|c|}{ Cations } \\
\hline \multicolumn{2}{|l|}{ (1) } & \multicolumn{2}{|c|}{$(2)^{b}$} \\
\hline $\mathrm{Cu}-\mathrm{N}(\mathrm{A})$ & $2.045(8)$ & $\mathrm{Cu}-\mathrm{N}(\mathrm{A})$ & $2.006(8)$ \\
\hline $\mathrm{Cu}-\mathrm{N}(\mathrm{B})$ & $2.053(9)$ & $\mathrm{Cu}-\mathrm{N}(\mathrm{B})$ & $2.071(5)$ \\
\hline $\mathrm{N}(\mathrm{A})-\mathrm{Cu}-\mathrm{N}\left(\mathrm{A}^{\mathrm{i}}\right)$ & $81.4(3)$ & $\mathrm{N}(\mathrm{A})-\mathrm{Cu}-\mathrm{N}(\mathrm{B})$ & $82.2(3)$ \\
\hline $\mathrm{N}(\mathrm{B})-\mathrm{Cu}-\mathrm{N}\left(\mathrm{B}^{\mathrm{i}}\right)$ & $80.9(3)$ & $\mathrm{N}(\mathrm{A})-\mathrm{Cu}-\mathrm{N}\left(\mathrm{A}^{\mathrm{l}}\right)$ & $146.0(3)$ \\
\hline $\mathrm{N}(\mathrm{A})-\mathrm{Cu}-\mathrm{N}(\mathrm{B})$ & $109.7(3)$ & $\mathrm{N}(\mathrm{A})-\mathrm{Cu}-\mathrm{N}\left(\mathrm{B}^{\prime}\right)$ & $115.8(3)$ \\
\hline $\mathrm{N}(\mathrm{A})-\mathrm{Cu}-\mathrm{N}\left(\mathrm{B}^{\mathrm{i}}\right)$ & $144.7(2)$ & $\mathrm{N}(\mathrm{B})-\mathrm{Cu}-\mathrm{N}\left(\mathrm{B}^{\prime}\right)$ & $118.5(2)$ \\
\hline
\end{tabular}

${ }^{a}$ Transformations of the asymmetric unit: $\mathrm{i} \bar{x}, y, \frac{1}{2}-z, \mathrm{I} 1-x, y, \frac{1}{2}-z$. ${ }^{b}$ For the anion of (2), $\mathrm{Cu}-\mathrm{Br}(1,2)$ are $2.209(2), 2.223(2) \AA$.

metry, $\mathrm{mm}$, the ligand planes lying normal to each other. Given the sparseness of the co-ordination sphere of the quite large metal atom in an environment of a pair of bidentate ligands, it would not be surprising if some departure from such an ideal array occurred. In fact, the maintenance of high symmetry is possible by degradation of the $\mathrm{mm}$ symmetry to 222 , releasing the constraint that the two ligand planes lie normal to each other. In (1), the cation disposition is such that the two-fold axis relates the two halves of each ligand to each other, so that the two ligands are independent. Although the interligand dihedral angle, $49.9^{\circ}$, is well removed from $90^{\circ}$, with interligand $\mathrm{N}-\mathrm{Cu}-\mathrm{N}$ angles differing widely $\left[109.7(3), 144.7(2)^{\circ}\right]$, the cation symmetry remains a good approximation to 222 , as evidenced by the angles $\theta_{x}$ and $\theta_{y}$ both assuming values of $90.0^{\circ}{ }^{*} \mathrm{Cu}-\mathrm{N}$ distances are similar $[2.045(8), 2.053(9) \AA]$ and comparable with the values observed in $\left[\mathrm{Cu}(\mathrm{dmphen})_{2}\right]^{+}$[range $2.027(5)$ $2.053(5) \AA]{ }^{4}$ In the latter species, however, it seems that the bulky methyl substituents exercise more control over the relative disposition of the two ligands, as the maximum $\mathrm{N}-\mathrm{Cu}-\mathrm{N}$ angle observed among a wide range of salts is $135.2^{\circ}$, and the minimum $114.7(2)^{\circ}$. The cation of $(2)$ is disposed so that the 2 axis passes between the ligands, effectively diminishing its control over the total cation symmetry. Here only one $\mathrm{N}-\mathrm{Cu}-\mathrm{N}$ angle is large $\left[146.0(3)^{\circ}\right]$, the other three being clustered together $\left[2 \times 115.8(3) ; 118.5(2)^{\circ}\right]$. In this cation the dihedral angle between the ligands is much greater, being $76.8^{\circ}$; however the cation as a whole is considerably distorted from the $c a .222$ $\begin{array}{llll}\text { symmetry found for (1) with } \theta_{x} & 103.3^{\circ} \text { and } \theta_{y} & 100.2^{\circ} \text {. This }\end{array}$ distortion is also apparent in the differences observed for the $\mathrm{Cu}-\mathrm{N}$ bond lengths where the two bonds which subtend the large angle are appreciably shorter than any $\mathrm{Cu}-\mathrm{N}$ bond described above, being $2.006(8) \AA$, while the other pair of bonds are lengthened to 2.071(5) $\AA$. In neither (1) nor (2) does the anion interact with the copper atom of the cation, despite the lack of steric constraints on the ligands that would preclude such interactions.

A comparison of the $\mathrm{CuN}_{4}$ core geometries of the present complexes with $\left[\mathrm{Cu}(\text { tmen })_{2}\right]^{+9}$ (tmen $=N N N^{\prime} N^{\prime}$-tetramethylethylenediamine) shows that for the bulky aliphatic ligand, the core geometry approaches ideal $\mathrm{mm}$ symmetry: with $\mathrm{Cu}-\mathrm{N}$ $2.13(1)-2.16(1) \quad \AA$; intraligand $\mathrm{N}-\mathrm{Cu}-\mathrm{N}$ angles $85.3(4)$, $86.0(4)^{\circ}$; interligand angles $122.9(4), 121.6(4), 123.1(4), 122.5(5)^{\circ}$ (theoretical for $m m$ symmetry, $122.3^{\circ}$ ); $\theta_{x} 91.0, \theta_{y} 89.5$, dihedral angle $90.3^{\circ}$.

${ }^{*} \theta_{x}$ and $\theta_{y}$ are defined as follows: $\theta_{x}$ is the angle between the bisector of the $\mathrm{N}(\mathrm{B})-\mathrm{Cu}-\mathrm{N}\left(\mathrm{B}^{\mathrm{i}}\right)$ angle $(\xi)$ and the normal to the $\mathrm{N}(\mathrm{A})-\mathrm{Cu}-\mathrm{N}\left(\mathrm{A}^{\mathrm{i}}\right)$ plane; $\theta_{y}$ is the angle between $\xi$ and the vector lying in the $\mathrm{N}(\mathrm{A})-\mathrm{Cu}-\mathrm{N}\left(\mathrm{A}^{\mathrm{i}}\right)$ plane perpendicular to the bisector of the $\mathrm{N}(\mathrm{A})-\mathrm{Cu}-$ $N\left(A^{i}\right)$ angle (see also ref. 4 ). 
Table 4. Intercation contacts $(\mathrm{C} \ldots \mathrm{C}, \mathrm{N}<3.7 \AA)^{a}$ for complexes (1) and (2)

\begin{tabular}{ll}
\multicolumn{3}{c}{ Complex (1) } \\
$\mathrm{N} \cdots \mathrm{C}(6 \mathrm{~A})$ & $3.55(1)$ \\
$\mathrm{C}(1 \mathrm{~A}) \cdots \mathrm{C}(4 \mathrm{~A})$ & $3.55(1)$ \\
$\mathrm{C}(1 \mathrm{~A}) \cdots \mathrm{C}(6 \mathrm{~A})$ & $3.46(1)$ \\
$\mathrm{C}(2 \mathrm{~A}) \cdots \mathrm{C}(3 \mathrm{~A})$ & $3.60(1)$ \\
$\mathrm{C}(2 \mathrm{~A}) \cdots \mathrm{C}(4 \mathrm{~A})$ & $3.52(1)$ \\
$\mathrm{C}(3 \mathrm{~A}) \cdots \mathrm{C}(5 \mathrm{~A})$ & $3.57(1)$ \\
$\mathrm{C}(4 \mathrm{~A}) \cdots \mathrm{C}(5 \mathrm{~A})$ & $3.63(1)$
\end{tabular}

In both (1) and (2), irrespective of cation symmetry or lack of it, cation-cation charge-transfer interactions appear to comprise significant factors in controlling crystal packing. In Figure 1, a correct impression is given of peripheral overlap between centrosymmetrically related ligands B; more substantial overlap between centrosymmetrically related ligands $A$ is achieved and depicted in Figure 3, with close contacts listed in Table 4. Substantial ligand-ligand overlaps are also achieved in (2) (Table 4, Figure 3), in spite of the less symmetrical packing array $\{c f$. Figure 3 of the preceding paper for $[\mathrm{CuCl}(\mathrm{dmphen})]\}$. In (2), the copper atom lies appreciably out of the ligand plane (by $0.164 \AA$ ).

Finally, given the general interest in $\mathrm{Cu}^{\mathrm{II}}-\mathrm{Cu}^{\mathrm{I}}$ redox chemistry and the search for copper(II) and copper(I) complexes with similar core geometries, it is of value to compare the present structures with copper(II) complexes of the type [CuX(phen) $\left.)_{2}\right] \mathrm{Y}$, where $\mathrm{X}^{-}$and $\mathrm{Y}^{-}$are weakly co-ordinating anions. For example, for $\left[\mathrm{Cu}\left(\mathrm{O}_{2} \mathrm{CMe}\right)(\text { phen })_{2}\right]\left[\mathrm{BF}_{4}\right],{ }^{10} \mathrm{Cu}-\mathrm{N}$ are $2.010(2), 2.025(2), 2.062(2), 2.218(2) \AA$; intraligand $\mathrm{N}-\mathrm{Cu}-\mathrm{N}$ angles, 81.3(1), 79.1(1) ${ }^{\circ}$; interligand angles 95.1(1), 103.5(1), 97.6(1), 174.6(1) ${ }^{\circ}$, dihedral angle, $101.2^{\circ}$. Similar trends have also been observed for related dmphen complexes. ${ }^{11}$

\section{References}

1 H. A. Goodwin, D. L. Kepert, J. M. Patrick, B. W. Skelton, and A. H. White, Aust. J. Chem., 1980, 37, 1817 and refs. therein.

2 G. del Piero, G. Perego, A. Zazzetta, and G. Brandi, Cryst. Struct. Commun., 1975, 4, 521 .

3 G. Smith, E. J. O'Reilly, C. H. L. Kennard, and A. H. White, J. Chem. Soc., Dalton Trans., 1977, 1184.

4 J. F. Dobson, B. E. Green, P. C. Healy, C. H. L. Kennard, C. Pakawatchai, and A. H. White, Aust. J. Chem., 1984, 37, 649 and refs. therein.

5 P. C. Healy, C. Pakawatchai, and A. H. White, preceding paper

6 C-W. Lee and F. C. Anson, Inorg. Chem., 1984, 23, 837.

7 M. Asplund, S. Jagner, and M. Nilsson, Acta Chem. Scand., Ser. A, $1983,37,57$

8 R. P. Shibaeva and V. F. Kaminskii, Sov. Phys.-Crystallogr. (Engl. Transl.), 1981, 26, 188.

9 L. M. Engelhardt, R. I. Papasergio, and A. H. White, Aust. J. Chem., $1984,37,2207$.

10 W. Fitzgerald and B. Hathaway, Acta. Crystrallogr., Sect.C, 1984, 40, 243.

11 P. J. Burke, K. Henrick, and D. R. McMillin, Inorg. Chem., 1982, 21, 1881.

Received 17th July 1984; Paper 4/1241 